\title{
MENINGKATKAN MUTU ASN IHDN DENPASAR DENGAN PELAYANAN PUBLIK BERBASIS TAT TWAM ASI
}

\author{
Oleh \\ Ni Luh Gede Wariati \\ Tenaga Pendidik pada Fakultas Brahma Widya IHDN Denpasar
}

\begin{abstract}
The understanding and application of ethical values are essential in providing excellent service to the community. One kind of success of an institution is when it is able to provide excellent service to the community. Tat TvamAsi is one ofHindu philosophies that is loaded with ethical or moral values, it means that "he/she (him/her) is you." To provide excellent service, then it is highly needed innovations and efforts so that the goals can be realized as well. By applying the teachings of Tat TvamAsi, then ASN will realize that in fact we are all the same, then there will be no discrimination in providing services. IHDN is also one of the educational institutions that seek to improve quality in order to attract people to become members of the great family of this institute. To attract people and gain the trust of society, one of the efforts that can be done is to improve the quality of service in IHDN Denpasar. Tat Tvam Asi-based services could be a new innovation to improve the environmental quality of service in IHDN Denpasar.
\end{abstract}

Keywords: Tat TvamAsi, service, ASNquality

\section{PENDAHULUAN}

Pegawai Negeri Sipil (PNS) yang sekarang dikenal dengan sebutan Aparatur Sipil Negara (ASN) turut serta memberi kontribusi dalam kemajuan negara Indonesia. ASN yang profesional serta memiliki loyalitas terhadap lembaga, sangat diperlukan dalam melaksanakan tugas dan tanggung jawab dalam memberi pelayanan prima tidak hanya untuk negara namun juga untuk masyarakat. Seorang ASN hendaknya mampu untuk memberi pelayanan dan pemahaman kepada masyarakat guna mensukseskan kebijakan pemerintah. Pelayanan dan pemahaman yang jelas akan membantu masyarakat dalam melaksanakan program pemerintah dan secara tidak langsung dapat mensukseskan program pemerintah.
Dalam melaksanakan tugasnya seorang ASN hendaknya mampu untuk menjalin komunikasi yang baik terhadap atasan, rekan kerja dan masyarakat guna membangun suasana kerja yang menyenangkan dan sehat. Suasana kerja yang sehat dan menyenangkan juga akan menunjang semangat kerja dan akhirnya memberi dampak yang positif terhadap hasil kerja ASN.

Dalam membangun suasana kerja yang menyenangkan seorang ASN hendaknya memahami tentang pentingknya etika atau sopan santun dalam berkomunikasi. Pemerintah menyatakan bahwa dalam melaksanakan tugasnya, seorang ASN hendaknya mengaktualisasikan nilai-nilai Akuntabilitas, Nasionalisme, Etika Publik, Komitmen Mutu 
dan Anti Korupsi yang disingkat ANEKA. Harapan pemerintah bagi ASN agar mampu mengaktualisasikan nilai ANEKA menunjukkan bahwa etika menjadi hal penting yang harus dimiliki seorang ASN. Pemahaman dan penerapan nilai-nilai etika sangat penting dalam memberikan pelayanan prima bagi masyarakat. Salah satu bentuk kesuksesan sebuah lembaga adalah mampu memberikan pelayanan prima bagi masyarakat.

IHDN adalah salah satu lembaga pendidikan tinggi berbasis agama yang bernaung dibawah kementerian agama. ASN dalam lingkungan kerja IHDN terdiri dari dua bagian yaitu tenaga pengajar (dosen) dan pegawai. ASN dalam lingkungan IHDN dituntut untuk memberi pelayanan yang maksimal bagi masyarakat dalam hal ini bagi mahasiswa pada khususnya. Penerapan ajaran agama dalam melakukan pelayanan publik sangat diharapkan karena selain IHDN merupakan lembaga pendidikan berbasis agama namun pendidikan etika dan susila juga banyak dibuat dalam ajaran agama Hindu. Dengan melaksanakan pelayanan berbasis etika agama hindu diharapkan mampu meningkatkan mutu ASN di lingkungan IHDN Denpasar.

Ajaran agama Hindu sarat dengan nilai-nilai etika di dalamnya, salah satu ajaran etika Hindu adalah Tat Twam Asi. Ajaran ini sangat sederhana namun memiliki makna yang mendalam. Penerapan ajaran Tat Twam Asi dalam memberikan pelayanan publik seharusnya bisa membentuk pelayanan prima dalam melayani masyarakat.

\section{PEMBAHASAN}

\subsection{Tat Twam Asi sebagai dasar melakukan pelayanan}

Tat Twam Asi adalah salah satu fisafat hindu yang sarat dengan nilai etika atau susila. Menurut agama Hindu etika sama dengan susila. Kata susila berasal dari sansekerta "Sila: yang berarti tingkah laku. Mendapat awalan "Su" yang berarti baik. Kata susila berarti sikap/ tingkah laku yang baik dan benar (Karda, I Made dkk, 2007:59-60). Pemahaman dan pelaksanaan tingkah laku yang baik dan benar sangat diperlukan dalam setiap aktivitas. Agama hindu memandang susila merupakan sesuatu yang penting karena itu susila merupakan salah satu bagian dari tri kerangka dasar agama hindu.

Tri kerangka dasar agama hindu adalah tiga pegangan dasar yang harus dimiliki dalam melaksanakan kegiatan keagamaan. Adapun bagian dari tri kerangka dasar agama hindu adalah tatwa, susila dan upacara. Tatwa merupakan landasan filsafat, susila merupakan landasan tingkah laku yang benar dan upacara adalah bentuk aktivitas keagamaan. Ketiga hal tersebut saling mendukung satu sama lain dan sama-sama penting untuk dilaksanakan. Tri kerangka dasar agama hindu sering digambarkan sebagai sebutir telur, dimana tatwa adalah kuning telur, susila adalah putih telur dan upacara adalah kulit telur, ketiganya sama pentingnya dan saling menunjang.

Pemahaman tentang susila dalam aktivitas hidup sangat diperlukan oleh masyarakat. Dengan memahami susila maka akan individu akan dapat dengan mudah melakukannya. Suwantana, I Gede (2004:111) menyebutkan bahwa:

Individu yang baik adalah individu yang selalu melakukan tindakan sesuai dengan tatanan yang berlaku di masyarakat. Kesadaran untuk mematuhi hukum atau aturan muncul di dari dalam diri. Kesadaran ini menjadi kunci keberhasilan seseorang didalam melakoni kehidupannya berdasarkan tatanan yang ada. Jalan bagi kesadaran ini adalah pengetahuan diri (self-knowledge). Untuk menjadi baik, orang harus memiliki pengetahuan akan kebaikan itu.

Berdasarkan kutipan di atas dapat dipahami bahwa pengetahuan tentang susila akan menuntun individu untuk memiliki kesadaran tentang kebaikan dan akhirnya dengan kesadaran tersebut maka individu akan terdorong untuk melakukan kebaikan itu. 
Karena itulah pembelajaran dan pengetahuan tentang susila Hindu menjadi sangat penting diberikan kepada masyarakat. Karena hanya dengan pengetahuan seseorang akan dapat melepaskan diri dari kekeliruan dan perbuatan salah.

Salah satu ajaran susila hindu adalah Tat Twam Asi. Sudharta dalam Karda, I Made dkk, 2007:18 menyebutkan bahwa :

Tat Twam Asi adalah kata-kata filsafat dalam agama Hindu yang mengajarkan kesosialan yang tanpa batas karena diketahui bahwa "ia adalah kamu" saya adalah kamu dan segala makhluk adalah sama sehingga menolong orang lain berarti menolong diri sendiri dan menyakiti orang lain berarti menyakiti diri sendiri. Jiwa sosial ini juga juga diresapi oleh sinar-sinar tuntunan suci Tuhan dan tidak jiwa kebendaan. Tat artinya Itu (Ia), Twam artinya Kamu dan Asi artinya adalah.

Dari kutipan di atas dapat diketahui bahwa Tat Twam Asi salah satu ajaran susila hindu yang berarti "itu (ia) adalah kamu". Secara sederhana kalimat tersebut menyatakan bahwa kamu dan ia adalah sama, tidak ada bedanya, itu artinya bahwa kita semua adalah sama. Karena kita semua adalah sama maka apa yang kita lakukan kepada orang lain itu juga kita lakukan pada diri kita sendiri. Menghina, menyakiti dan menjatuhkan orang lain sama dengan menghina dan menyakiti diri sendiri. Membantu dan menghormati orang lain sama dengan menghormati diri sendiri.

Konsep yang hampir sama juga disampaikan oleh Confucius ketika berusaha menjelaskan tentang kebajikan yang sempurna. Dalam Fung Yu-Lan (2007:53) disebutkan bahwa dalam Untaian Ajaran, Confucius disebutkan berkata "Manusia Jen adalah orang yang karena berkeinginan untuk mengukuhkan dirinya, maka ia mengukuhkan orang lain, dan karena ingin mengembangkan dirinya, maka ia mengembangkan orang lain. Mampu menarik garis persamaan yang berpangkal dari dirinya dalam memperlakukan orang lain; itu bisa disebut sebagai jalan dalam mempraktikkan jen" (VI,28). Manusiajen yang dimaksud oleh Confusius bersinonim dengan manusia serba baik, dan jen dalam konteks ini dapat diterjemahkan sebagai "kebajikan yang sempurna". Jadi dalam pemikiran Confucius ini dapat detangkap bahwa manusia yang serba baik adalah manusia yang menyadari bahwa antara dirinya dan orang lain adalah sama. Itu artinya bahwa ketika kita melakukan sesuatu kepada orang lain, sebenarnya bahwa kita sedang melakukan sesuatu untuk kita sendiri, karena orang lain itu adalah sama dengan kita.

Sat Guru Satya Narayana dalam Donder (2006:20) mengatakan;

If you want happiness and

If you want peace,

You must give love.

Only through love will yaou find true happiness.

Only through love will you find inner peace.

Therefore, develop your love, live in love.

Love lives by giving and forgiving.

Artinya :

Jika engkau menginginkan kebahagiaan, dan

Jika engkau menginginkan kedamaian, Engkau harus memberikan kasih, Hanya melalui kasih engkau akan mendapatkan kebahagiaan sejati, Hanya melalui kasih engkau akan memperoleh kedamaian batin,

Karena itu, kembangkanlah kasihmu, hiduplah dalam kasih.

Kasih hidup dengan memberi dan memaafkan.

Ketika menginginkan sesuatu jangan takut untuk memberi, karena dengan memberi kita tidak akan kehilangan apa-apa bahkan akan mendapatkan sesuatu yang lebih besar. 
Mengasihi orang lain seperti kita mengasihi diri kita sendiri akan membimbing pada kebahagiaan sejati dan kedamaian batin. Memahami ajaran Tat twam asi, membuat kita dapat melihat bahwa sesungguhnya semua terlahir di dunia memiliki tujuan yang sama, seperti yang terdapat dalam Rgveda X.191.4 :

"Saman va akutih, samana hrdayani vah;

Samanam astu vo namo, yatha va susahasati”

Artinya :

Samalah hendaknya tujuanmu, samalah hendaknya hatimu dengan demikian semoga semua hidup berbahagia bersamasama.

Dari sloka di atas dapat dipahami bahwa ketika kita menyadari bahwa tujuan kita adalah sama, maka kita akan mengetahui bahwa hati kita juga sama sehingga kesadaran akan persamaan yang begitu besar dalam diri kita, yang menyadarkan kita bahwa persamaan ini akan menuntun kita hidup berbahagia bersamasama.

Konsep yang hampir sama dengan Tat Twam Asi juga sering diajarkan oleh orang tua kita, konsep ini disebut dengan "ngikut raga". Konsep nyikut raga ini sudah dimiliki oleh masyarakat Bali sejak dahulu. Orang tua kita terdahulu sering mengatakan:

Amen sing demen cacade, do nyacad timpal.

Amen sing demen kaplokinne, do ngalaplokin timpal.

Artinya :

Kalau tidak suka dihina, jangan menghina teman (orang lain)

Kalau tidak suka dipukul, jangan memukul teman (orang lain)
Itulah yang disebut konsep nyikut raga dimana kita dibimbing untuk tidak melakukan sesuatu yang tidak ingin orang lain lakukan kepada kita dan selalu menggunakan diri kita menjadi ukuran dalam melakukan sesuatu kepada orang lain. Konsep ini menekankan tentang tingkah laku, karena bila menggunakan ukuran diri kita maka kita akan memperlakukan orang lain seperti kita memperlakukan diri kita sendiri.

Pemahaman tentang Tat Twam Asi lebih dalam dari sekedar nyikut raga. Karena pelaksanaan Tat Twam Asi tidak hanya sekedar memperlakukan orang lain sama dengan memperlakukan diri sendiri, namun juga menyadari bahwa diri kita dan yang lain adalah sama tidak ada bedanya. memahami bahwa pada dasarnya tujuan kita adalah sama, karena itu kita hendaknya melakukan secara bersamasama. Hal pertama yang dilakukan untuk mengaplikasikan ajaran Tat Twam Asi dalam tindakan kita adalah dengan menekan ego kita. Ego dalam diri kita yang menjadi penghalang bagi kita untuk menyadari bahwa pada dasarnya kita semua adalah sama. 'Aku', milikku, hidupku dan lain-lain tentang 'aku', itulah kegelapan dalam diri yang membuat kita menjadi buta dalam memandang kehidupan yang sebenarnya.

Pravrajika Vrajaprana (2014:40) menjelaskan bahwa hal yang mencegah kita menyadari kebenaran adalah ego, rasa 'aku' dan 'milikku'. Seperti guru spiritual besar Ramakrishna mengatakan "perasaan 'aku' dan 'milikku' telah menutupi realitas sehingga kita tidak melihat kebenaran." Dia lebih lanjut mengatakan "ketika ego mati, semua masalah berhenti." Dari perkataan Ramakrishna tersebut kita dapat mengetahui bahwa ego adalah hal yang sangat berbahaya, yang membuat kita menjadi tidak mampu melihat kebenaran. Cara utama dalam menghentikan segala masalah adalah dengan menghilangkan ego kita. Pengetahuan tentang menghilangkan ego adalah kunci utama dalam melaksanakan tat twam asi. 
Karena ketika ego dalam diri kita sudah mati kita akan menyadari bahwa yang ada bukan 'aku' ataupun 'milikku' namun yang sebenarnya ada adalah 'kita semua sama' dan apa yang ada di dunia ini bahkan nafas ini bukanlah milik kita.

Seseorang yang dihormati karena jabatan, kepandaian, kekayaan dan hal-hal baik lainnya hendaknya selalu berupaya untuk tetap sadar. Ketika seseorang berada pada puncak, maka sering kali dijatuhkan oleh ego. Merasa diri hebat dan selalu lebih dari yang lain merupakan salah satu bentuk ego yang berlebihan. Memandang remeh orang lain karena kepandaian yang kita miliki merupakan bagian dari ego yang berlebihan. Perilaku seperti itulah yang menyebabkan manusia menjadi merasa dirinya berbeda dengan yang lain. Ajahn Brahm (2015:84) menyebutkan bahwa :

Jika anda mencarapi apapun dalam hal ini, jika meditasi anda cukup baik, atau jika pemahaman anda mengenai ajaran atau disiplin sangatlah mendalam dan terpelajar, mohon jangan pernah menganggap hal-hal tadi sebagai "milikku", "pengetahuanku”, "pencapaianku”

Dari kutipan diatas Ajahn Brahm berusaha menjelaskan bahwa penghormatan yang diberikan seseorang kepada kita karena jabatan, kekayaan, kepandaian dan hal-hal baik yang lainnya merupakan bentuk godaan yang besar dalam menekan ego. Cara terbaik untuk lepas dari ego adalah menganggap dan menyadari bahwa apapun yang kita peroleh, bukanlah milik kita. Penghormatan yang diberikan kita karena kita adalah orang yang memiliki pengetahuan tinggi, sebenarnya penghormatan itu tidak diberikan kepada kita, namun kepada pengetahuan yang kita punya. Cara sederhana seperti itu dapat membantu kita untuk perlahan melepaskan diri dari ego dan menganggap semua yang ada pada kita adalah 'milikku'.

\subsection{Penerapan ajaran Tat Twam Asi dalam pelayanan publik}

ASN tidak bisa lepas dari masyarakat sebagai pengguna jasa, karena itu seorang ASN dituntut untuk mampu memberi pelayanan kepada publik sesuai dengan bidangnya. Dalam melakukan pelayanan publik dan menjalankan tugasnya, ASN hendaknya mengikuti kode etik Aparatur Sipil Negara. Berdasarkan Undangundang ASN, kode etik dan kode perilaku ASN yakni sebagai berikut:

1. Melaksanakan tugas dengan jujur, bertanggung jawab dan berintegritas tinggi.

2. Melaksanakan tugasnya dengan cermat dan disiplin.

3. Melayani dengan sikap hormat, sopan dan tanpa tekanan.

4. Melaksanakan tugasnya sesuai dengan peraturan perundangan yang berlaku.

5. Melaksanakan tugasnya sesuai dengan perintah atasan atau pejabat yang berwenang sejauh tidak bertentangan dengan ketentuan peraturan perundang-undangan dan etika pemerintah.

6. Menjaga kerahasiaan yang menyangkut kebijakan negara.

7. Menggunakan kekayaan dan barang milik negara secara bertanggung jawab, efektif dan efisien.

8. Menjaga agar tidak terjadi konflik kepentingan dalam melaksanakan tugas.

9. Memberikan informasi secara benar dan tidak menyesatkan kepada pihak lain yang memerlukan informasi terkait kepentingan kedinasan.

10. Tidak menyalah gunakan informasi intern negara, tugas, status, kekuasaan, dan jabatannya untuk mendapat atau mencari keuntungan atau manfaat bagi diri sendiri atau untuk orang lain. 
11. Memegang teguh nilai dasar ASN dan selalu menjaga reputasi dan integritas ASN.

12. Melaksanakan ketentuan peraturan perundang-undanganmengenai disiplin pegawai ASN.

Kode etik ASN mencoba untuk menuntun dan membimbing ASN menuju kepada pelayanan prima. Aturan atau kode etik dibuat untuk membentuk ASN yang profesional dan berkualitas. Paham idealisme mengatakan bahwa pada dasarnya setiap manusia adalah baik dan suka hal-hal yang baik. Apabila orangorang yang menyimpang dari kebaikan, itu sebata-mata karena dia tidak tahu norma untuk bertindak dengan baik atau tidak tahu caracara bertindak yang menuju ke arah kebaikan. Hal yang diperlukan adalah suatu peringatan dan sentuhan nurani yang terus menerus untuk menggugah kesadaran moral dan melestarikan nilai-nilai tersebut dalam kehidupan dan interaksi antar individu. (Tim Penyusun, 2014:51)

Keduabelas kode etik ASN tersebut harusnya dijadikan pedoman dalam melakukan pelayanan publik guna menuju pelayanan prima. Sebagai ASN dalam menjalankan tugas negara akan berhubungan dengan masyarakat, karena ASN sebagai peghubung dalam menjalankan kebijakan pemerintah. Pelayanan yang maksimal kepada masyarakat diharapkan mampu memaksimalkan program pemerintah agar dampaknya benar-benar dirasakan oleh masyarakat. ASN dalam menjalankan tugasnya hendaknya memberikan pelayanan yang maksimal dan penuh kesabaran.

ASN diharapkan mampu memberikan pelayanan prima bagi masyarakat. Dalam http:/ /apkexcellent.blogspot.com disebutkan bahwa Ada tiga konsep dasar (A3) yang harus diperhatikan dalam mewujudkan pelayanan prima, yakni: Konsep sikap (attitude), Konsep perhatian (attention) dan Konsep tindakan (action) a. Konsep sikap (attitude)

Sikap ASN dalam memberi informasi kepada masyarakat adalah penilain pertama yang diberikan oleh masyarakat kepada lembaga pemerintah. Sikap ramah, sopan dan santun hendaknya dimiliki oleh ASN dalam berkomunikasi baik kepada atasan, rekan kerja ataupun masyarakat. "Bahasa menunjukkan Bangsa" peribahasa itu maksudnya adalah baik buruk seseorang atau tabiat seseorang ditunjukkan oleh bahasanya, jadi hendaknya sebagai seorang ASN harus bisa menjaga sikap dan bahasa demi menjaga nama baik lembaga dan Negara.

Sikap yang diharapkan berdasarkan konsep pelayanan prima adalah:

1) Sikap pelayanan prima berarti mempunyai rasa kebanggaan terhadap pekerjaan

2) Memiliki pengabdian yang besar terhadap pekerjaan

3) Senantiasa menjaga martabat dan nama baik perusahaan

b. Konsep perhatian (attention)

Dalam melakukan kegiatan layanan, seorang ASN hendaknya memberikan perhatian terhadap masalah dan keinginan masyarakat yang berhubungan dengan lembaga tempat dia berkerja. Masyarakat sebagai penerima jasa agar merasa diperhatikan dan dilayani dengan tulus sehingga apa yang menjadi tujuan lembaga pemerintahan dapat menyentuh masyarakat secara langsung. Hal-hal lain yang perlu diperhatikan menyangkut bentuk-bentuk pelayanan berdasarkan konsep perhatian adalah sebagai berikut:

1) Mengucapkan salam pembuka pembicaraan.

2) Menanyakan apa saja keinginan masyarakat.

3) Mendengarkan dan memahami keinginan masyarakat. 
4) Melayani masyarakat dengan cepat, tepat dan ramah.

c. Konsep tindakan (action)

Pada konsep perhatian, masyarakat "menunjukkan minat" untukinformasi yang akan kita berikan. Pada konsep tindakan masyarakat sudah "menjatuhkan pilihan" untuk bergabung dan mendukung program yang ditawarkan oleh lembaga tempat kita bekerja.

Bentuk-bentuk pelayanan berdasarkan konsep tindakan adalah sebagai berikut:

1) Segera mencatat segala hal penting.

2) Menegaskan kembali kebutuhan masyarakat.

3) Mengucapkan terimakasih.

Untuk memberikan pelayanan yang prima maka dibutuhkan inovasi dan usaha agar apa yang menjadi tujuan bersama bisa terealisasi dengan baik. Melaksanakan pelayanan publik dengan berdasarkan Tat Twam Asi merupakan salah satu cara untuk menuju pelayanan prima. Dengan menerapkan ajaran Tat Twam Asi maka ASN akan menyadari bahwa sebenarnya kita semua adalah sama, maka tidak akan ada diskriminasi dalam memberikan pelayanan. Pelaksanaan pelayanan dengan berdasarkan Tat Twam Asi dapat dilakukan dengan tindakan sebagai berikut:

\section{a. Menghilangkan ego}

Dalam Bagus (2000:179) disebutkan bahwa ego berasal dari bahasa Latin yang berarti aku, saya jadi ego berarti diri individual. Egoisme adalah dokrin bahwa semua tindakan seseorang terarah atau harus terarah pada diri sendiri. Sikap mementingkan diri sendiri dan selalu melakukan sesuatu yang hanya menguntungkan diri merupakan bagian dari tindakan egosime. Dalam ajaran Hindu Sikap seperti itulah yang harus kita hilangkan. Dalam ajaran Tat Twam Asi, dijelaskan bahwa kita semua adalah sama. Aku dan kamu adalah sama.

Egomempengaruhi etika dan moralitas seseorang, karena seseorang yang dipengaruhi oleh ego secara berlebihan hanya akan melakukan sesuatu yang menguntungkan dirinya. Pravrajika Vrajaprana (2014:41) menyebutkan bahwa:

"Apakah memang ego memiliki hubungan dengan etika dan moralitas? Mutlak semuanya. Semua kode moral didasarkan kepada ideal tidak mementingkan diri sendiri: menempatkan orang lain sebelum diri kita sendiri, memaksa ego untuk bermain biola kedua. Mengikuti keinginan egois selalu merugikan kegiatan rohani kita. Apakah tindakan atau pikiran besar atau kecil, dan keegoisan akan membuat selubung ketidaktahuan lebih tebal dan lebih gelap. Sebaliknya setiap tindakan tidak mementingkan diri sendiri betapapun besar atau kecilnya, akan memiliki efek sebaliknya"

Dengan memberikan pelayanan tanpa mementingkan diri sendiri merupakan upaya untuk melepas selubung ketidak tahuan tentang hakikat diri, bahwa kita semua adalah sama. Seorang ASN yang berusaha memberikan pelayanan dengan tidak mementingkan diri sendiri maka tindakan itu secara tidak langsung akan menguntungkan masyarakat, lembaga tempat dia bekerja dan dirinya sendiri.

\section{b. Tidak Bersikap Diskriminasi}

Diskriminasi merujuk kepada pelayanan yang tidak adil terhadap individu tertentu, di mana layanan ini dibuat berdasarkan karakteristik yang diwakili oleh individu tersebut. Diskriminasi merupakan suatu kejadian yang biasa 
dijumpai dalam masyarakat manusia, ini disebabkan karena kecenderungan manusian untuk membeda-bedakan yang lain. Ketika seseorang diperlakukan secara tidak adil karena karakteristik suku, antargolongan, kelamin, ras, agama dan kepercayaan, aliran politik, kondisi fisik atau karateristik lain yang diduga merupakan dasar dari tindakan diskriminasi. (https://id.wikipedia.org/wiki/ Diskriminasi)

Sikap membenda-bedakan dalam memberikan pelayanan merupakan tindakan yang kurang bijaksana. Sebagai seorang ASN haruslah disadari bahwa semua masyarakat adalah sama, semua berhak menikmati layanan pemerintah dan mendapatkan informasi yang akurat untuk program pemerintah. Kaya atau miskin, laki-laki atau perempuan, pejabat atau masyarakat biasa, cantik atau jelek bukan merupakan dasar dalam memberikan pelayanan, karena semua hal itu hanyakah kulit luar dari manusia yang hakikatnya sama. Dalam Suwantana (2014:122) disebutkan :

Shatrau mitre putre bandhau ma kuru yatnam vigrahasandhau

Sarvasminnapi pashyatmanam sarvatrotsrija bhedagynanam (Bhaja Govindam, 25)

Artinya:

Bersikaplah sama terhadap lawan, kawan, anak dan kerabat tanpa dibuat-buat. Sadarilah kehadiran Sang Diri dimana-mana, bebaskan dirimu dari ketidak sadaran.

Dari kutipan di atas dapat diketahui bahwa hendaknya kita harus berlaku sama kepada semua orang. Hal inilah yang juga hendaknya digunakan dasar dalam melakukan pelayanan, bahwa semua orang harus dilayani dengan pelayanan yang sama. Kesadaran tentang Sang Diri yang ada dimana-mana merupakan pengetahuan yang harus dipegang teguh dalam melayani masyarakat.

\subsection{Meningkatkan Mutu ASN IHDN Denpasar dengan Pelayanan Publik berbasis Tat Twam Asi}

Mutu merupakan salah satu standar yang menjadi dasar untuk mengukur capaian hasil kerja. Mutu juga dapat dijadikan sebagai alat pembeda atau pembanding dengan produk/jasa sejenis lainnya, yang dihasilkan oleh lembaga lain sebagai pesaing (competitors). (Tim Penyusun, 2014: 22) Definisi di atas menunjukkan bahwa mutu menunjukkan kualitas kerja yang dimiliki oleh lembaga. Semakin bermutu suatu lembaga baik dalam bidang pelayanan, sarana dan prasarana maka semakin berkualitas juga lembaga tersebut. Mutu menjadi acuan masyarakat dalam memilih lembaga pendidikan, karena itulah sekarang lembaga pendidikan berlomba-lomba untuk memperbaiki diri agar dikatakan sebagai lembaga yang bermutu.

IHDN juga merupakan salah satu lembaga pendidikan yang berusaha untuk meningkatkan mutu demi menarik masyarakat untuk bergabung menjadi anggota dari keluarga besar institut ini. Untuk menarik minat masyarakat dan mendapatkan kepercayaan masyarakat, salah satu upaya yang dapat dilakukan adalah dengan meningkatkan mutu pelayanan di lingkungan IHDN Denpasar. Pelayanan berbasis Tat Twam Asi bisa menjadi inovasi baru guna meningkatkan mutu pelayanan di lingkungan IHDN Denpasar. Demi mendapatkan mutu yang diharapkan maka melalui pelayanan berbasis Tat Twam Asi IHDN dapat melaksanakan program yang efektivitas, efisiensi dan inovatif.

\section{a. Efektivitas}

Richard L. Daft dalam tim penyusun (2014:8) mendefinisikan efektivitas sebagai berikut. "efektivitas organisasi berarti 
sejauh mana organisasi dapat mencapai tujuan yang ditetapkan, atau berhasil mencapai apapun yang coba dikerjakannya. Efektivitas organisasi berarti memberikan barang atau jasa yang dihargai oleh pelanggan." Berdasarkan definisi tersebut maka suatu kegiatan dapat dikatakan efektiv bila apa yang menjadi kebijakan organisasi atau lembaga dapat diterima secara positif oleh masyarakat sebagai penerima jasa. Dengan melaksanakan pelayanan berbasis Tat Twam Asi maka pelayanan yang diberikan kepada masyarakat akan tulus dan iklas tanpa bersifat deskriminatif. Dengan pelayanan seperti itu informasi akan dapat dengan senang hati diterima oleh masyarakat. Pelayanan dengan dasar kesadaran bahwa kita semua adalah sama, akan menjadikan tidak ada sekat antara ASN sebagai pemberi jasa dengan masyarakat sebagai penerima jasa.

b. Efisiensi

Efisiensi diukur dari ketepatan realisasikegunaan sumberdaya dan bagaimana pekerjaan dilaksanakan, sehingga dapat diketahui ada atau tidak adanya pemborosan sumber daya, penyalah gunaan alokasi penyimpangan prosedur dan mekanisme yang keluar alur (Tim Penyusun, 2014: 9). Dengan melaksanakan pelayanan yang berbasis Tat Twam Asi maka tidak akan adanya pemborosan tenaga dan penyimpangan prosedur. ASN yang melakukan pelayanan dengan dasar pemahaman tentang Tat Twam Asi akan mampu memberikan informasi yang akurat kepada masyarakat sehingga masyarakat akan dapat menerima informasi secara menyeluruh. Sehingga pemborosan tenaga karena seringnya terjadi kesalah pahaman masyarakat akan informasi yang diterima bisa diminimalisir. c. Inovatif

Inovasi dalam memberikan pelayanan kepada masyarakat sangatlah diperlukan, untuk menemukan cara yang efisien dalam memberi pemahaman kepada masyarakat. Lembaga pemerintah dalam melaksanakan tugasnya haruslah inovatif dalam menjalankan programnya untuk menarik minat masyarakat agar program yang dicanangkan dapat sukses diterima. Lembaga pendidikan dewasa ini berlomba-lomba untuk membuat inovasi guna menarik minat masyarakat. Pelayanan berbasis Tat Twam Asi merupakan salah satu inovasi dalam bidang pelayanan. Dengan pemahaman akan Tat Twam Asi, maka akan memberi warna baru dalam pelayanan di lingkungan IHDN. Pelayanan yang awalnya sudah bagus dan ramah akan semakin hangat dan kekeluargaan. Hubungan yang terjadi dengan masyarakat akan semakin mendalam dan berkesan.

\section{SIMPULAN}

Tat Twam Asi adalah salah satu fisafat hindu yang sarat dengan nilai etika atau susila berarti “itu (ia) adalah kamu”. Secara sederhana kalimat tersebut menyatakan bahwa kamu dan ia adalah sama, tidak ada bedanya, itu artinya bahwa kita semua adalah sama. Karena kita semua adalah sama maka apa yang kita lakukan kepada orang lain itu juga kita lakukan pada diri kita sendiri. Menghina, menyakiti dan menjatuhkan orang lain sama dengan menghina dan menyakiti diri sendiri. Membantu dan menghormati orang lain sama dengan menghormati diri sendiri.

Untuk memberikan pelayanan yang prima maka dibutuhkan inovasi dan usaha agar apa yang menjadi tujuan bersama bisa terealisasi dengan baik. Melaksanakan pelayanan publik dengan berdasarkan Tat Twam Asi merupakan salah satu cara untuk menuju pelayanan prima. Dengan menerapkan ajaran Tat Twam Asi 
maka ASN akan menyadari bahwa sebenarnya kita semua adalah sama, maka tidak akan ada diskriminasi dalam memberikan pelayanan.

IHDN juga merupakan salah satu lembaga pendidikan yang berusaha untuk meningkatkan mutu demi menarik masyarakat untuk bergabung menjadi anggota dari keluarga besar institut ini. Untuk menarik minat masyarakat dan mendapatkan kepercayaan masyarakat, salah satu upaya yang dapat dilakukan adalah dengan meningkatkan mutu pelayanan di lingkungan IHDN Denpasar. Pelayanan berbasis Tat Twam Asi bisa menjadi inovasi baru guna meningkatkan mutu pelayanan di lingkungan IHDN Denpasar. Demi mendapatkan mutu yang diharapkan maka melalui pelayanan berbasis Tat Twam Asi IHDN dapat melaksanakan program yang efektivitas, efisiensi dan inovatif.

\section{DAFTAR PUSTAKA}

Anonim. 2010. Diskriminasi. https:// id.wikipedia.org/wiki/Diskriminasi diakses tanggal 12 Juni 2016

Anonim. 2013. Konsep Dasar Pelayanan Prima. http://apkexcellent.blogspot.com/ 2013/06/konsep-dasar-pelayananprima.html\#ixzz4BKhDXUwI diakses tanggal 12 Juni 2016

Brahm, Ajahn. 2015. Si Cacing dan Kotoran Kesayangannya 3. Awereness Publication
Donder, I Ketut. 2006. Sisya Sista : Pedoman Menjadi Siswa Mulia (Religiopsikososioedukatif). Surabaya : Paramita.

Fung Yu Lan. 2007. Sejarah Filsafat Cina. Yogyakarta: Pustaka Pelajar

Karda, I Made dkk. 2007. Sistem Pendidikan Agama Hindu. Surabaya : Paramita

Suwantana, I Gede. 2014. Vedanta dalam serpihan hidup sehari-hari. Ashram Gandhi Puri-Indra Udayana Istitute of Vedanta.

Tim Penyusun. 2014. Etika Publik. Modul Penyelenggaraan Perdana Pendidikan dan Pelatihan Calon Pegawai Negeri Sipil Prajabatan Golongan III. Jakarta : Lembaga Administrasi Negara.

Tim Penyusun. 2014. Kominten Mutu. Modul Penyelenggaraan Perdana Pendidikan dan Pelatihan Calon Pegawai Negeri Sipil Prajabatan Golongan III. Jakarta : Lembaga Administrasi Negara.

Vaswani, T.L. 2007. Bhagawad Gita (Nyanyian Tuhan). Surabaya: Paramita

Vrajaprana, Pravrajika. 2014. Vedanta Sebuah Pengantar Sederhana. Media Hindu

Undang-Undang No 5 Tahun 2014 tentang Aparatur Sipil Negara. 